\title{
Enhanced energy density of carbon-based supercapacitors using Cerium (III) sulphate as inorganic redox electrolyte
}

Patricia Díaz, Zoraida González, Ricardo Santamaría, Marcos Granda, Rosa Menéndez,

\section{Clara Blanco*}

Instituto Nacional del Carbón, INCAR-CSIC, P.O. Box, 73, 33080-Oviedo, Spain

\begin{abstract}
The energy density of carbon based supercapacitors (CBSCs) was significantly increased by the addition of an inorganic redox species $\left[\mathrm{Ce}_{2}\left(\mathrm{SO}_{4}\right)_{3}\right]$ to an aqueous electrolyte $\left(\mathrm{H}_{2} \mathrm{SO}_{4}\right)$. The development of the faradaic processes on the positive electrode not only significantly increased the capacitance but also the operational cell voltage of these devices (up to $1.5 \mathrm{~V}$ ) due to the high redox potentials at which the $\mathrm{Ce}^{3+} / \mathrm{Ce}^{4+}$ reactions occur. Therefore, in asymmetric CBSCs assembled using an activated carbon as negative electrode and MWCNTs as the positive one, the addition of $\mathrm{Ce}_{2}\left(\mathrm{SO}_{4}\right)_{3}$ moderately increases the energy density of the device (from $1.24 \mathrm{~W} \mathrm{~h} \mathrm{~kg}^{-1}$ to $5.08 \mathrm{~W} \mathrm{~h} \mathrm{~kg}^{-1}$ ). When a modified graphite felt is used as positive electrode the energy density of the cell reaches values as high as $13.84 \mathrm{~W} \mathrm{~h} \mathrm{~kg}^{-1}$. The resultant systems become asymmetric hybrid devices where energy is stored due to double layer formation in the negative electrode and the development of the faradaic process in the positive electrode, which acts as a battery-type electrode.
\end{abstract}

\footnotetext{
${ }^{*}$ Corresponding author: C. Blanco; Fax.: +34985297662; e-mail: clara@incar.csic.es
} 
KEYWORDS: hybrid supercapacitor, redox electrolyte, operational voltage, energy density, power density

\section{INTRODUCTION}

Supercapacitors (SCs) have been extensively developed as energy storage devices due to their high power density and long cycle life $[1,2]$. Although SCs were initially intended for shortterm pulse applications, they have attracted considerable attention in recent years on account of their possible use in high energy applications [3], such as electric and hybrid vehicles [2, 4]. As a result the improvement of energy density has become a matter of great importance [4]. The need to achieve higher energy densities has encouraged the development of many new types and designs of SCs.

The energy stored in a SC $(E)$ is given by Eq. (1):

$$
E=1 / 2 C V^{2}
$$

where $C$ represents the cell capacitance and $V$ is the applied cell voltage. Thus most strategies followed by the scientific community to increase the energy density values of SCs have been focused on the enhancement of one of these two parameters.

The attempts to increase capacitance of carbon-based supercapacitors (CBSCs) were initially focused on tailoring the surface area, pore size and pore size distribution of the carbon materials to maximize electrical double layer formation [5-7]. Despite great efforts, the energy densities achieved have never exceeded $10 \mathrm{~W} \mathrm{~h} \mathrm{~kg}^{-1}$. Consequently, the possibility of using the contribution of pseudocapacitance was also considered and carbons were modified 
with heteroatoms [8], transition metal oxides [9], polyoxometalates [10] or layered double hydroxide composites [11].

More recently, our research group proposed a highly efficient and low cost alternative to increase the cell capacitance of symmetric CBSCs based on the incorporation of electroactive organic molecules (organic redox electrolytes) such as hydroquinone, methylene blue or indigo carmine into the supporting electrolytes, a route that has been followed by other researchers [12-16]. In these electrochemical devices one of the electrodes (where the redox reactions occur) acts as a battery-type electrode, while the other one retains its capacitor-type behavior. The system can therefore be considered a symmetric hybrid SC, because the energy storage mechanisms of both electrodes are different. The mechanism of energy storage in such systems is described elsewhere [17].

The most effective way to increase the energy density values of these devices is to widen the operating cell voltage (see Eq. (1)). Several organic solvents and ionic liquids have been studied as high voltage electrolytes $[18,19]$. Although organic electrolytes are still the most widely used in commercial devices, economic, environmental and toxicity issues together with their low conductivity (which has a negative effect on the power density of the device) restrict their use and makes it necessary to search for other alternatives. It should also be borne in mind that the increase in voltage achieved by using these electrolytes is normally penalized by a decrease in capacitance with respect to aqueous electrolytes.

Some asymmetric hybrid devices developed not only take advantage of the high capacitances of aqueous systems but also incorporate other electrode materials that allow a wider cell voltage to be used. Carbon/ $\mathrm{MnO}_{2}$ asymmetric systems are probably the most commonly studied in this category $[20,21]$, although other materials such as $\mathrm{Ni}(\mathrm{OH})_{2}$ and $\mathrm{LiMn}_{2} \mathrm{O}_{4}$ have also been investigated $[22,23]$. The aim of this work is to increase the energy density of 
carbon-based supercapacitors by enhancing not only the cell capacitance but also the operating cell voltage. Previous studies of the mechanisms involved in a symmetric system using hydroquinone as redox electrolyte [17] have demonstrated that the use of activated carbon in the negative electrode increases the overpotential of the hydrogen evolution reaction, making it possible to work up to $-0.6 \mathrm{~V}$ vs. $\mathrm{Ag} / \mathrm{AgCl} / 3.5 \mathrm{M} \mathrm{KCl}$ as reference electrode. Therefore, the operating cell voltage could be widened by adding a reversible redox couple with a redox potential higher than that of hydroquinone $(+0.4 \mathrm{~V}$ vs. $\mathrm{Ag} / \mathrm{AgCl} / 3.5 \mathrm{M}$ $\mathrm{KCl}$ ). Therefore, for the present study the redox couple $\mathrm{Ce}^{3+} / \mathrm{Ce}^{4+}$, with a redox potential of $1.15 \mathrm{~V}$ vs. $\mathrm{Ag} / \mathrm{AgCl} / 3.5 \mathrm{M} \mathrm{KCl}$ and which has been widely studied as positive electrolyte in redox flow batteries [24-26] was selected as the electroactive species in order to build asymmetric hybrid capacitors that use an activated carbon $(A C)$ in the negative electrode and multiwalled carbon nanotubes (MWCNTs) or a modified graphite felt $(G F)$ in the positive one.

\section{EXPERIMENTAL}

\subsection{Materials}

Commercial multi-walled carbon nanotubes (MWCNTs, $\mathrm{S}_{\mathrm{BET}} \approx 210 \mathrm{~m}^{2} \mathrm{~g}^{-1}$, Sigma-Aldrich) and a modified commercial graphite felt $\left(G F, \mathrm{~S}_{\mathrm{BET}} \approx 3 \mathrm{~m}^{2} \mathrm{~g}^{-1}\right)$, were investigated as active materials for the positive electrode of SCs. $G F$ was obtained by the thermal treatment of a commercial felt (RVG-2000, Mersen) at $1000{ }^{\circ} \mathrm{C}$ under a $\mathrm{N}_{2}$ flow $\left(150 \mathrm{~mL} \mathrm{~min}^{-1}\right)$ for 1 hour. An activated carbon $\left(A C, \mathrm{~S}_{\mathrm{BET}} \approx 2000 \mathrm{~m}^{2} \mathrm{~g}^{-1}\right)$ was used as negative electrode of the different SCs studied. This was obtained in the laboratory by chemical activation of a mesophase pitch with $\mathrm{KOH}(\mathrm{KOH} /$ pitch ratio $3: 1)$ at $700{ }^{\circ} \mathrm{C}$ for $1 \mathrm{~h}$, under a $\mathrm{N}_{2}$ flow of $62 \mathrm{ml} \mathrm{min}^{-1}$ [27]. The disk-shaped $A C$ or $M W C N T s$ electrodes (geometric area $\approx 1.13 \mathrm{~cm}^{2}$ ) were prepared by mixing 90 wt. $\%$ of the corresponding carbon material and 10 wt. $\%$ of 
polytetrafluoroethylene (PTFE) as binder. Electrodes from $G F$ were obtained by cutting disks of similar dimensions with a puncher, but without using any binder.

Solutions of $0.15 \mathrm{M} \mathrm{Ce}_{2}\left(\mathrm{SO}_{4}\right)_{3} / 1.0 \mathrm{M} \mathrm{H}_{2} \mathrm{SO}_{4}$ were used as electrolyte. The supporting electrolyte (1.0 $\left.\mathrm{M} \mathrm{H}_{2} \mathrm{SO}_{4}\right)$ was also studied for comparative purposes.

\subsection{Electrochemical characterization}

All the electrochemical measurements were performed on a BioLogic VMP Multichannel Potentiostat/Galvanostat at room temperature.

The electrochemical behavior of the different electrode materials both in the supporting and in the redox electrolytes was studied by cyclic voltammetry using a three-electrode cell. The cell consisted of electrodes of $A C, M W C N T s$ or $G F$ as the working electrodes, a $\mathrm{Ag} / \mathrm{AgCl} / 3.5 \mathrm{M}$ $\mathrm{KCl}$ as reference electrode and a graphite rod as counter electrode (Fig. S1A, Supplementary Data).

Two-electrode asymmetric cells were prepared for their electrochemical characterization, both of them with $A C$ as the negative electrode, and MWCNTs or $G F$ as the positive one ( $A C / M W C N T$ and $A C / G F$, respectively). The mass ratio between the positive and negative electrode was (1:1) for $A C / M W C N T$ and (2:3) for $A C / G F$. These systems were tested both using $1.0 \mathrm{M} \mathrm{H}_{2} \mathrm{SO}_{4}\left(A C / \mathrm{H}_{2} \mathrm{SO}_{4} / M W C N T\right.$ and $\left.A C / H_{2} \mathrm{SO}_{4} / G F\right)$ and in $0.15 \mathrm{M} \mathrm{Ce}_{2}\left(\mathrm{SO}_{4}\right)_{3} / 1.0 \mathrm{M}$ $\mathrm{H}_{2} \mathrm{SO}_{4}\left(A C / C e-H_{2} \mathrm{SO}_{4} / M W C N T\right.$ and $\left.A C / C e-H_{2} \mathrm{SO}_{4} / G F\right)$ as supporting and redox electrolytes, respectively.

The cell voltage profile and the potential evolution of each electrode during the galvanostatic cycling of the devices were simultaneously monitored by performing synchronous cyclic chronopotentiometric tests (GCPL, $17.7 \mathrm{~mA} \mathrm{~cm}^{-2}$ ) in a "T-type" Swagelok ${ }^{\circledR}$ cell using a 2-3 electrode configuration (Fig. S1B, Supplementary Data). To obtain this configuration a twoelectrode cell was assembled and at the third-end connection an $\mathrm{Ag} / \mathrm{AgCl} / 3.5 \mathrm{M} \mathrm{KCl}$ 
reference electrode was incorporated, making it possible to determine the potential at which each electrode was operating when a determined cell voltage was applied.

The electrochemical behavior of the two asymmetric SCs was studied in a two-electrode configuration Swagelok $^{\circledR}$ cell (Fig. S1C, Supplemetary Data) by performing GCPL tests (0.9$88.4 \mathrm{~mA} \mathrm{~cm}^{-2}$ ) at $1.0 \mathrm{~V}$ and at $1.5 \mathrm{~V}$. Moreover, the long-term stability of the SCs (up to 3,000 cycles) was evaluated by galvanostatic cycling between $0 \mathrm{~V}$ and $1.5 \mathrm{~V}$ at a constant current density of $44 \mathrm{~mA} \mathrm{~cm}{ }^{-2}$. During this study electrochemical impedance spectroscopy experiments (EIS, at $0.0 \mathrm{~V} ; 1 \mathrm{mHz}-100 \mathrm{kHz} ; \pm 10 \mathrm{mV}$ ) were also performed every 1,000 cycles in order to monitor the evolution of the cell resistance with cycling.

Capacitance values $(C)$ were obtained from the galvanostatic discharge profiles taking into account the different energy storage mechanisms involved [28]. The cell capacitance values were obtained in a two-electrode configuration by applying Eq. (3) to the mentioned discharge profiles in the intervals where the system exhibits a linear voltage variation with time:

$$
C=I . \Delta t_{d} / \Delta V_{d} \cdot m_{t}
$$

where $I$ is the current applied, $\Delta t_{d}$ is the discharge time, $\Delta V_{d}$ is the discharge voltage and $m_{t}$ is the total mass of active electrode material in the cell. The electrode capacitance values were calculated by applying the same Eq. (3) to the discharge profiles recorded on a 2-3 electrode configuration cell.

The energy density values $(E)$ were calculated by integrating the galvanostatic discharge profiles (avoiding the ohmic drop) recorded on a two-electrode cell for the cell energy or on a 2-3 electrode configuration cell for every single electrode [29]. 


\section{RESULTS AND DISCUSSION}

\subsection{Selection of electrode materials}

The selection of the electrode materials for a hybrid asymmetric supercapacitor is critical for ensuring the correct performance of the device. The choice of an activated carbon as active material for the negative electrode is evident, as the main charge storage mechanism in this electrode is electrical double layer formation, and so a high surface area material is required. In this respect, chemically activated mesophase-derived ACs have demonstrated their excellent performance as electrode materials in supercapacitors [27, 30-32].

However, the choice of materials for the positive electrode is not so straightforward. The $\mathrm{Ce}^{3+} / \mathrm{Ce}^{4+}$ couple was selected as electroactive species for this study due to its highly positive redox potential. Therefore, the positive electrode material has to be able to withstand strong oxidant environments, a quality not possessed by many carbon materials. Two carbon materials were selected as possible candidates for the positive electrode. On the one hand, MWCNTs have a relatively large surface area, a high chemical inertness, a good electrical conductivity and have demonstrated a good performance with other redox electrolytes $[12,15$, 16]. On the other hand, modified graphite felts have been widely used as electrodes in redox flow batteries and have demonstrated their ability to withstand oxidant environments while maintaining a good electrical conductivity and performing well as an "electron-transfer surface" $[33-35]$.

The electrochemical behavior of $M W C N T S$ and $G F$ in $\mathrm{H}_{2} \mathrm{SO}_{4}$ and $\mathrm{Ce}_{2} \mathrm{H}_{2} \mathrm{SO}_{4}$ media was initially studied by means of cyclic voltammetry measurements carried out using a threeelectrode cell configuration (Fig. 1). The behavior of $A C$ was also analysed for comparative purposes. As might be expected, $A C$ shows a significantly higher capacitance due to its larger 
surface area, but the maximum potential that can be reached with this electrode is $0.6 \mathrm{~V}$ (versus $\mathrm{Ag} / \mathrm{AgCl} / 3.5 \mathrm{M} \mathrm{KCl}$ ), and even then an oxidation current is evident. In contrast MWCNTs, despite their lower capacitance, are able to withstand higher potentials, the oxidation current being significant only above $0.85 \mathrm{~V}$. It is also worth noting that no oxidation current is apparent in the case of $G F$ up to $1.2 \mathrm{~V}$ versus $\mathrm{Ag} / \mathrm{AgCl} / 3.5 \mathrm{M} \mathrm{KCl}$, indicating that there is a huge overpotential of oxygen evolution on this electrode.

After the addition of $\mathrm{Ce}^{3+}$ ions to the supporting electrolyte (Fig. 1B), an intense electrochemical signal at around $1.2 \mathrm{~V}$ vs. $\mathrm{Ag} / \mathrm{AgCl} / 3.5 \mathrm{M} \mathrm{KCl}$ is observed on the MWCNTs electrode, corresponding to the $\mathrm{Ce}^{3+} / \mathrm{Ce}^{4+}$ redox reactions. However two overlapping processes can be appreciated in the oxidation peak whereas there is only one in the reduction one, which might indicate the irreversible oxidation of the electrode material in addition to the oxidation of $\mathrm{Ce}^{3+}$. When $G F$ is used as electrode, only the peaks corresponding to the $\mathrm{Ce}^{3+} / \mathrm{Ce}^{4+}$ reactions are observed, reflecting the stability of this material as shown, in Fig. 1A. It is also worth noting that the peak currents measured on the $G F$ electrode are similar to those corresponding to the $M W C N T s$, in spite of their different BET apparent surface areas. A possible explanation for this may be found in the huge ionic radius of the $\mathrm{Ce}$ ions [Ce(III): 11.5-12.8 $\mathrm{nm}$ and Ce (IV): 10.1-1.1 nm, depending on the coordination index $(6 \mathrm{u} 8$ respectively)], that might hinder their access to the inner surface of the MWCNTs pores, making only the external surface area of the nanotubes suitable for the reaction.

\subsection{Study of asymmetric systems}

Two-electrode asymmetric SCs were therefore prepared for electrochemical characterization, both with the same negative electrode $(A C)$ but with different positive electrodes (MWCNTS or $G F$ ). First both systems were subjected to tests at $1.0 \mathrm{~V}$, the results of which are shown in Fig. 2. The results obtained for the systems containing $M W C N T s\left(A C / \mathrm{H}_{2} \mathrm{SO}_{4} / M W C N T\right.$ and 
$A C / C e-H_{2} \mathrm{SO}_{4} / M W C N T$, Fig. $2 \mathrm{~A}$ and B respectively) indicate that the addition of $\mathrm{Ce}^{3+}$ neither improves the performance of the cell nor modifies the mechanism of energy storage, as the triangular shape typical of EDLCs remains unchanged.

The situation is totally different when $G F$ is used as positive electrode. In sulphuric media (Fig. 2C) the charge/discharge profile maintains the characteristic triangular shape of EDLCs but the capacitance of the cell is now very low as a result of the lower surface area of the felt used as electrode. Nevertheless the situation changes noticeably when $\mathrm{Ce}^{3+}$ is added to the supporting electrolyte (Fig. 2D). The capacitance of the cell increases significantly and the shape of the profile is far from being a triangle, which implies a change in the mechanism of energy storage. From 0 to $0.85 \mathrm{~V}$ the voltage rises rapidly due to the low capacitance of the positive electrode, but above $0.85 \mathrm{~V}$ the slope levels off, probably due to the presence of $\mathrm{Ce}^{3+}$ ions.

In order to gain a deeper understanding of the processes involved in the operation of the cell during the galvanostatic charge/discharge, the potential evolution profiles of the positive and negative electrodes were synchronously recorded. Fig. 3 shows the behavior of both electrodes (positive and negative) in the different systems.

Unlike conventional symmetric EDLCs [17], the distribution of potentials between the positive and negative electrodes in the $\mathrm{AC} / \mathrm{H}_{2} \mathrm{SO}_{4} / \mathrm{MWCNT}$ system is not identical (Fig. 3A). This behavior is explained by the difference in capacitance derived from the different surface areas of $A C$ and $M W C N T s$, as is deduced from Eq. (2).

$$
m_{+} \cdot C_{+} \cdot \Delta V_{+}=m_{-} \cdot C_{-} \cdot \Delta V_{-}
$$

where $m_{+}$and $m_{-}, C_{+}$and $C_{-}, \Delta V_{+}$and $\Delta V_{-}$represent the mass, the capacitance and the potential range of the positive and negative electrode, respectively. In this case both 
electrodes were prepared with identical masses, so that the cell voltage distribution between both electrodes is determined by their capacitance.

The addition of $\mathrm{Ce}^{3+}$ to the supporting electrolyte (Fig. 3B) does not introduce any change to the system, either on the positive or on the negative electrode. The reasons for this behavior can be easily deduced from Fig. 1. The redox potential of the $\mathrm{Ce}^{3+} / \mathrm{Ce}^{4+}$ couple is $1.15 \mathrm{~V}$ vs. $\mathrm{Ag} / \mathrm{AgCl} / 3.5 \mathrm{M} \mathrm{KCl}$ while the maximum potential that the positive electrode reaches in the $\mathrm{AC} / \mathrm{Ce}-\mathrm{H}_{2} \mathrm{SO}_{4} / \mathrm{MWCNT}$ system is $1.0 \mathrm{~V}$, making the presence of the electroactive species useless.

The situation dramatically changes when $G F$ is used as the positive electrode (Fig. 3C and D). As mentioned before, the capacitance of the device in sulphuric media $\left(A C / \mathrm{H}_{2} \mathrm{SO}_{4} / G F\right)$ is very low due to the very low capacitance of $G F$. According to Eq. (2), the negative electrode $(A C)$, which has a high capacitance, hardly varies its working potential range whereas the positive electrode occupies nearly the whole range of cell potential variation reaching a potential of $1.20 \mathrm{~V}$ vs. the reference electrode. It is worth noting that, although the negative electrode behaves almost like a battery (constant electrode potential) there is no reason to assume that the energy storage mechanism on this electrode is anything else but the electrical double layer formation.

The addition of $\mathrm{Ce}^{3+}\left(\mathrm{AC} / \mathrm{Ce}-\mathrm{H}_{2} \mathrm{SO}_{4} / G F\right.$, Fig. 3D) causes a drastic change in capacitance for the reasons explained above. The positive electrode reaches a potential where the $\mathrm{Ce}^{3+} / \mathrm{Ce}^{4+}$ redox reaction can occur. The plateau observed in the positive electrode profile confirms the development of the above-mentioned faradaic processes on this electrode which transforms the asymmetric cell into an asymmetric hybrid device [28], where the energy storage mechanism of the positive electrode (faradaic processes) differs from the mechanism of the negative one (electrical double layer formation). 
An examination of the potential evolution profiles in Fig. 3 leads to a proper interpretation of the processes that are occurring in the cell, something that is much more difficult to achieve when only two-electrode cell galvanostatic charge/discharge curves are used (Fig. 2). Moreover, from an analysis of Fig. 3B and 3D it can be inferred that the operating cell voltage could be extended to at least $1.5 \mathrm{~V}$. When the applied cell voltage is $1.0 \mathrm{~V}$, the negative electrode is working at around $0.2 \mathrm{~V}$ versus the reference electrode (Fig. 3D), but it is well known that this activated carbon can work at much more negative potentials without provoking the hydrogen evolution reaction $[17,36]$. Consequently, it can be predicted that, if the operating cell voltage is increased, the positive electrode will remain within the potential of the $\mathrm{Ce}^{3+} / \mathrm{Ce}^{4+}$ reactions, while the negative electrode will shift to more negative potentials.

Fig. 4 shows the results obtained for both cells $\left(\mathrm{AC} / \mathrm{Ce}-\mathrm{H}_{2} \mathrm{SO}_{4} / \mathrm{MWCNTS}\right.$ and $\mathrm{AC} / \mathrm{Ce}$ $\mathrm{H}_{2} \mathrm{SO}_{4} / G F$ ) when they are operating at $1.5 \mathrm{~V}$. The galvanostatic charge-discharge cycles of both systems (Fig. 4A and 4B) show certain similarities but also some differences. During the charge and discharge processes two zones can be clearly observed, the first one (Zone I) with a much larger capacitance than the other (Zone II).

In the case of the $\mathrm{AC} / \mathrm{Ce}-\mathrm{H}_{2} \mathrm{SO}_{4} / G \mathrm{~F}$ device the differences are even more noticeable, there being a larger capacitance in Zone I, and a change in slope at a lower cell voltage $(0.80 \mathrm{~V})$. In the $\mathrm{AC} / \mathrm{Ce}-\mathrm{H}_{2} \mathrm{SO}_{4} / \mathrm{MWCNT}$ system the slope changes at a cell voltage of around $1.15 \mathrm{~V}$. A deeper insight into the processes involved in each zone can again be obtained from the potential evolution profiles of the positive and negative electrodes (Fig. 4C and 4D). Additionally, Tables 1 and 2 show the quantitative data calculated from the two-electrode cells and the individual electrodes for the two zones mentioned above.

As can be observed from the data in Table 2 and in Fig. 4B, for $A C / C e-H_{2} S_{4} / G F$, Zone I shows a slow discharge process between $1.5 \mathrm{~V}$ and $0.72 \mathrm{~V}$, and a cell specific capacitance of 
$64 \mathrm{~F} \mathrm{~g}^{-1}$. Examination of the behavior of each individual electrode (Fig. 4D) evidences that the positive electrode has a higher capacitance $\left(408 \mathrm{~F} \mathrm{~g}^{-1}\right)$ due to the development of the $\mathrm{Ce}^{3+} / \mathrm{Ce}^{4+}$ redox reactions. Therefore the energy storage mechanism of this electrode must be faradaic, as demonstrated by the very small change in $\Delta V(0.18 \mathrm{~V})$. In this zone the limiting electrode is the negative one, with $A C$ storing the energy in the double layer.

The main characteristic of Zone II is the very rapid discharge (Fig. 4B). Consequently the cell specific capacitance is very low (only $4 \mathrm{~F} \mathrm{~g}^{-1}$ ). The reason for this fast drop in voltage is that the positive electrode potential is working below the redox potential of the $\mathrm{Ce}^{3+} / \mathrm{Ce}^{4+}$ couple and therefore the electrochemical reaction does not occur. It is at this point that $G F$ stores the energy in the double layer and, due to its very low surface area, the capacitance of the positive electrode is very small $\left(6 \mathrm{~F} \mathrm{~g}^{-1}\right)$. The positive electrode has now become the limiting electrode, with the negative electrode showing a much larger capacitance $\left(343 \mathrm{~F} \mathrm{~g} \mathrm{~g}^{-1}\right)$ and, therefore, making only a negligible contribution to the capacitor as a whole, as can be deduced from Eq. (3).

$$
1 / C=1 / C_{+}+1 / C
$$

The very small change in $\Delta V$ for the negative electrode $(0.01 \mathrm{~V})$ might lead one to think that its behavior is faradaic but such a low variation in potential can be explained by taking into account Eq. (2).

The hybrid system $\mathrm{AC} / \mathrm{Ce}-\mathrm{H}_{2} \mathrm{SO}_{4} / \mathrm{MWCNT}$ behaves in a similar way though there are small but significant differences (Fig. 4A, Table 1). Zone I, when the positive electrode is working as a battery, is restricted to a smaller voltage range (from $1.50 \mathrm{~V}$ to $1.13 \mathrm{~V}$ ). Thus, most of the energy is stored in Zone II, with both the positive and negative electrodes storing charge through the double layer formation. This reduces the contribution of the redox reactions and 
therefore the energy density of the system is not greatly improved. These results indicate that the larger surface area of $M W C N T s$ with respect to $G F$, which might initially be thought of as beneficial, becomes the main obstacle to an increase in the energy stored in the hybrid system, since the contribution of the $\mathrm{Ce}^{3+} / \mathrm{Ce}^{4+}$ redox reactions decreases.

To conclude, the addition of cerium ions to the electrolyte allows increasing the cell voltage, leading to an enhancement in the energy density of the cell, but to different extents depending on the positive electrode material. Thus, in the case of the $\mathrm{AC} / \mathrm{Ce}-\mathrm{H}_{2} \mathrm{SO}_{4} / \mathrm{MWCNT}$ device the energy density reaches $5.08 \mathrm{~W} \mathrm{~h} \mathrm{~kg}^{-1}$ (the energy density value obtained for the system without cerium was $1.24 \mathrm{~W} \mathrm{~h} \mathrm{~kg}^{-1}$ ). The enhancement in energy achieved for the $A C / C e$ $\mathrm{H}_{2} \mathrm{SO}_{4} / G F$ is even greater, reaching a value of $13.84 \mathrm{~W} \mathrm{~h} \mathrm{~kg}^{-1}$ (the value obtained for the system without cerium was only $0.02 \mathrm{~W} \mathrm{~h} \mathrm{~kg}^{-1}$ ). This is a notable value of energy, since the typical energy values of conventional symmetric EDLC devices that use similar activated carbons as electrodes are never higher than $10 \mathrm{~W} \mathrm{~h} \mathrm{~kg}^{-1}[17]$.

\subsection{Long term behavior}

Once the mechanisms of energy storage in each electrode have been understood it becomes important to study the long-term behavior of these systems. The high redox potential of the $\mathrm{Ce}^{3+} / \mathrm{Ce}^{4+}$ couple has the advantage that it allows the operating cell voltage to be increased up to $1.5 \mathrm{~V}$. However, but the positive carbon electrode is exposed to a highly oxidative environment that might compromise its long-term performance.

Fig. 5 shows the long-term behavior of the $\mathrm{AC} / \mathrm{Ce}-\mathrm{H}_{2} \mathrm{SO}_{4} / \mathrm{MWCNT}$ device. The system shows a poor long-term electrochemical performance, as the initial $E\left(5 \mathrm{~W} \mathrm{~h} \mathrm{~kg}^{-1}\right)$ falls by $27 \%$ after 1,000 charge/discharge cycles (Fig. 5A). An increment in the cell resistance is observed with cycling (Fig. 5B) which might be attributed to the progressive oxidation of MWCNTs in the 
acidic medium since the redox potential of this reaction is close that of the $\mathrm{Ce}^{3+} / \mathrm{Ce}^{4+}$ redox processes (Fig. 1B).

The long-term behavior of the $A C / C e-H_{2} S_{4} / G F$ system at $1.5 \mathrm{~V}$ is shown in Fig. 6. The results indicate a good long-term behavior as there is only a decrease of $6 \%$ in the energy density after 3,000 galvanostatic charge/discharge cycles (Fig. 6A). In this case, the energy density is significantly higher than that obtained for the system containing MWCNTs (14 W h $\mathrm{kg}^{-1}$ vs. $5 \mathrm{~W} \mathrm{~h} \mathrm{~kg}^{-1}$ ). As can be seen from the results obtained by impedance spectroscopy (Fig. 6B), the resistance of the cell does not increase with cycling, which is in agreement with the greater chemical stability of the $G F$ electrode (Fig. 1B).

\section{CONCLUSIONS}

The use of $\mathrm{Ce}_{2}\left(\mathrm{SO}_{4}\right)_{3} / \mathrm{H}_{2} \mathrm{SO}_{4}$ as redox electrolyte is a highly effective method to enhance the energy density of asymmetric carbon-based supercapacitors. The presence of cerium ions transforms the device into a hybrid system. The positive electrode functions as a battery due to the development of the faradaic processes associated to the $\mathrm{Ce}^{3+} / \mathrm{Ce}^{4+}$ redox reactions, which significantly increase the capacitance. Meanwhile the mechanism of energy storage operating on the negative electrode continues to be the formation of the electrical double layer. Additionally, the operating cell voltage of these devices can widened to $1.5 \mathrm{~V}$, due to the high redox potentials at which the $\mathrm{Ce}^{3+} / \mathrm{Ce}^{4+}$ redox reactions occur. Both the increase in capacitance and operating cell voltage contribute to enhancing the energy density of the system. Thus, in asymmetric supercapacitors assembled using an activated carbon as negative electrode and MWCNTs as the positive one, the addition of $\mathrm{Ce}_{2}\left(\mathrm{SO}_{4}\right)_{3}$ moderately increases the energy density of the device (from $1.24 \mathrm{~W} \mathrm{~h} \mathrm{~kg}^{-1}$ to $5.08 \mathrm{~W} \mathrm{~h} \mathrm{~kg}^{-1}$ ). When a modified 
graphite felt is used as the positive electrode the energy density of the cell reaches values as high as $13.84 \mathrm{~W} \mathrm{~h} \mathrm{Kg}^{-1}$, and the cell exhibits an excellent long-term performance with an energy density loss of only $6 \%$ after 3,000 galvanostatic charge-discharge cycles.

\section{ACKNOWLEDGMENTS}

The authors thank MINECO (project MAT2010-20601-C02-01) for the financial support provided. Patricia Díaz thanks FPI predoctoral research grant (FPI:BES-2011-045394).

\section{REFERENCES}

[1] B. E. Conway in Electrochemical Supercapacitors: Scientific Fundamentals and Technological Applications, Kluwer Academic Publishers/Plenum Press, New York, 1999.

[2] A. Burke, Ultracapacitors: why, how, and where is the technology, J. Power Sources 91 (2000) 37.

[3] R. Kötz, M. Carlen, Principles and applications of electrochemical capacitors, Electrochim. Acta 45 (2000) 2483.

[4] P. Simon, Y. Gogotsi, Materials for electrochemical capacitors, Nat. Mat.7 (2008) 845.

[5] F. Béguin, E. Frackowiak in Carbon Materials for Electrochemical Energy Storage Systems, CRC Press, Taylor \& Francis, Boca Raton, 2010.

[6] C. Largeot, C. Portet, J. Chmiola, P.L. Taberna, Y. Gogotsi, P. Simon, Relation between the Ion Size and Pore Size for an Electric Double-Layer Capacitor, J. Am. Chem. Soc. $130(2008) 2730$. 
[7] E. Raymundo-Piñero, K. Kierzek, J. Machnikowski, F. Béguin, Relationship between the nanoporous texture of activated carbons and their capacitance properties in different electrolytes, Carbon 44 (2006) 2498.

[8] E. Frackowiak, G. Lota, J. Machnikowski, K. Kierzek, C. Fix, F. Béguin, Optimisation of supercapacitors using carbons with controlled nanotexture and nitrogen content, Electrochim. Acta 51 (2005) 2209.

[9] J.M. Sieben, E. Morallón, D. Cazorla-Amorós, Flexible ruthenium oxide-activated carbon cloth composites prepared by simple electrodeposition methods, Energy 58 (2013) 519.

[10] V. Ruiz, J. Suárez-Guevara, P. Gomez-Romero, Hybrid electrodes based on polyoxometalate-carbon materials for electrochemical supercapacitors, Electrochem. Commun. 24 (2012) 35.

[11] Y. Wimalasiri, R. Fan, X.S. Zhao, L. Zou, Assembly of Ni-Al layered double hydroxide and graphene electrodes for supercapacitors, Electrochim. Acta 134 (2014) 127.

[12] S. Roldán, C. Blanco, M. Granda, R. Menéndez, R. Santamaría, Towards a Further Generation of High-Energy Carbon-Based Capacitors by Using Redox-Active Electrolytes, Angew. Chem. Int. Ed. 50 (2011) 1699.

[13] H. Yu, J. Wu, L. Fan, Y. Lin, K. Xu, Z. Tang, C. Cheng, S. Tang, J. Lin, A novel redox-mediated gel polymer electrolyte for high-performance supercapacitor, J. Power Sources 198 (2012) 402 .

[14] G. Wang, R. Liang, L. Liu, B. Zhong, Improving the specific capacitance of carbon nanotubes-based supercapacitors by combining introducing functional groups on carbon nanotubes with using redox-active electrolyte, Electrochim. Acta 115 (2014) 183. 
[15] S. Roldán, M. Granda, R. Menéndez, R. Santamaría, C. Blanco, Supercapacitor modified with methylene blue as redox active electrolyte, Electrochim. Acta 83 (2012) 241.

[16] S. Roldán, Z. González, C. Blanco, M. Granda, R. Menéndez, R. Santamaría, Redoxactive electrolyte for carbon nanotube-based electric double layer capacitors, Electrochim. Acta 56 (2011) 3401.

[17] S. Roldán, M. Granda, R. Menéndez, R. Santamaría, C. Blanco. Mechanisms of energy storage in carbon-based supercapacitors modified with a quinoid redox-active e lectrolyte, J. Phys. Chem. C 115 (2011) 17606.

[18] I. Bispo-Fonseca, J. Aggar, C. Sarrazin, P. Simon, J.F. Fauvarque, Possible improvements in making carbon electrodes for organic supercapacitors, J. Power Sources 79 (1999) 238.

[19] D. Wei, T.W. Ng, Application of novel room temperature ionic liquids in flexible supercapacitors, Electrochem. Commun. 11 (2009) 1996.

[20] T. Brousse, M. Toupin, D. Bélanger, A Hybrid Activated Carbon-Manganese Dioxide Capacitor using a Mild Aqueous Electrolyte, J. Electrochem. Soc. 151 (2004) A614.

[21] V. Khomenko, E. Raymundo-Piñero, F. Béguin, Optimisation of an asymmetric manganese oxide/activated carbon capacitor working at $2 \mathrm{~V}$ in aqueous medium, J. Power Sources 153 (2006)183.

[22] J. H. Park, O. O. Park, K. H. Shin, C. S. Jin, J. H. Kim, An Electrochemical Capacitor Based on a $\mathrm{Ni}(\mathrm{OH})_{2} /$ Activated Carbon Composite Electrode, Electrochem. Solid-State Lett. 5 (2002) H7.

[23] Y-G. Wang, Y-Y. Xia, A new concept hybrid electrochemical surpercapacitor: Carbon/LiMn2O4 aqueous system, Electrochem. Commun. 7 (2005) 1138. 
[24] A. Paulenova, S.E. Creager, J.D. Navratil, Y. Wei, Redox potentials and kinetics of the $\mathrm{Ce}^{3+/} \mathrm{Ce}^{4+}$ redox reaction and solubility of cerium sulfates in sulfuric acid solutions, J. Power Sources 109 (2002) 431.

[25] Z. Xie, Q. Liu, Z. Chang, X. Zhang, The developments and challenges of cerium halfcell in zinc-cerium redox flow battery for energy storage, Electrochim. Acta 90 (2013) 695.

[26] G. Nikiforidis, L. Berlouis, D. Hall, D. Hodgson, Impact of electrolyte composition on the performance of the zinc-cerium redox flow battery system, J. Power Sources 243 (2013) 691.

[27] E. Mora, V. Ruiz, R. Santamaría, C. Blanco, M. Granda, R. Menéndez, J.M. JuarezGalán, F. Rodríguez-Reinoso, Influence of mesophase activation conditions on the specific capacitance of the resulting carbons, J. Power Sources 156 (2006) 719.

[28] S. Roldán, D. Barreda, M. Granda, R. Menéndez, R. Santamaría, C. Blanco, An approach to classification and capacitance expressions in electrochemical capacitors technology, Phys. Chem. Chem. Phys. 17 (2015) 1084.

[29] G. Z. Chen, Understanding supercapacitors based on nano-hybrid materials with interfacial conjugation, Progress in Nat. Sci.: Mat. Int. 23(3) (2013) 245.

[30] V. Ruiz, C. Blanco, E. Raymundo-Piñero, V. Khomenko, F. Béguin, R. Santamaría, Effects of thermal treatment of activated carbon on the electrochemical behavior in supercapacitors, Electrochim. Acta $52(200794969$.

[31] V. Ruiz, C. Blanco, M. Granda, R. Menéndez, R. Santamaría, Influence of electrode preparation on the electrochemical behavior of carbon-based supercapacitors, J. Appl. Electrochem. 37 (2007) 717. 
[32] V. Ruiz, C. Blanco, M. Granda, R. Menéndez, R. Santamaría, Effect of the thermal treatment of carbon-based electrodes on the electrochemical performance of supercapacitors, J. Electroanal. Chem. 618 (2008) 17.

[33] Z. González, A. Sánchez, C. Blanco, M. Granda, R. Menéndez, R. Santamaría, Enhanced performance of a Bi-modified graphite felt as the positive electrode of a vanadium redox flow battery, Electrochem. Commun. 13 (2011) 1379.

[34] Y. Shao, X. Wang, M. Engelhard, C. Wang, S. Dai, J. Liu, Z. Yang, Y. Lin, Nitrogendoped mesoporous carbon for energy storage in vanadium redox flow batteries, J. Power Sources 195 (2010) 4375.

[35] X. Wu, H. Xu, Y. Shen, P. Xu, L. Lu, J. Fu, H. Zhao, Treatment of graphite felt by modified Hummers method for the positive electrode of vanadium redox flow battery, Electrochim. Acta 138 (2014) 264.

[36] V. Ruiz, S. Roldán, I. Villar, C. Blanco, R. Santamaría, Voltage dependence of carbonbased supercapacitors for pseudocapacitance quantification, Electrochim. Acta 95 (2013) 225. 


\section{Figure Captions}

Fig. $1 \mathrm{CVs}$ recorded on the $A C, M W C N T S$ and $G F$ electrodes in (A) $1.0 \mathrm{M} \mathrm{H}_{2} \mathrm{SO}_{4}$ and (B) $0.15 \mathrm{M} \mathrm{Ce}_{2}\left(\mathrm{SO}_{4}\right)_{3} / 1.0 \mathrm{M} \mathrm{H}_{2} \mathrm{SO}_{4}\left(v_{\text {scan }}=5 \mathrm{mV} \mathrm{s}^{-1}\right)$.

Fig. 2 Galvanostatic charge/discharge profiles obtained at $1.0 \mathrm{~V}$ and $17.7 \mathrm{~mA} \mathrm{~cm}^{-2}$ for (A) $A C / H_{2} \mathrm{SO}_{4} / M W C N T$; (B) $A C / C e-H_{2} S_{4} / M W C N T$; (C) $A C / H_{2} S_{4} / G F$ and (D) $A C / C e-$ $\mathrm{H}_{2} \mathrm{SO}_{4} / G F$.

Fig. 3 Potential profiles for the positive and negative electrodes obtained in the cells (A) $A C / H_{2} \mathrm{SO}_{4} / M W C N T$ (B) $A C / C e-H_{2} S_{4} / M W C N T$ (C) $A C / H_{2} S_{4} / G F$ and (D) $A C / C e-$ $\mathrm{H}_{2} \mathrm{SO}_{4} / \mathrm{GF}$, applying a cell voltage of $1.0 \mathrm{~V}$ at $17.7 \mathrm{~mA} \mathrm{~cm}^{-2}$.

Fig. 4 Galvanostatic cycles at a cell voltage of $1.5 \mathrm{~V}$ obtained at a constant current of 17.7 $\mathrm{mA} \mathrm{cm}{ }^{-2}$ for (A) $A C / C e-H_{2} S_{4} / M W C N T$ and (B) $A C / C e-H_{2} S_{4} / G F$ cells, and the corresponding potential profiles for the positive and negative electrodes (C,D).

Fig. 5 Long term behavior of the $A C / C e-H_{2} S_{4} / M W C N T$ device in a two-electrode configuration: (A) Evolution of energy density values at $1.5 \mathrm{~V}$ and at a constant current of $44.3 \mathrm{~mA} \mathrm{~cm}^{-2}$; (B) Nyquist plots recorded at $0.0 \mathrm{~V}$.

Fig. 6 Long term behavior of the $\mathrm{AC} / \mathrm{Ce}-\mathrm{H}_{2} \mathrm{SO}_{4} / \mathrm{GF}$ device in a two-electrode configuration: (A) Evolution of energy density values at $1.5 \mathrm{~V}$ and at a constant current of $44.3 \mathrm{~mA} \mathrm{~cm}^{-2}$; (B) Nyquist plots recorded at $0.0 \mathrm{~V}$. 


\section{Table Captions}

Table 1. Cell or electrode capacitances $\left(C, C_{+}, C_{-}\right)$and energy density $(E)$ values calculated in the different zones for the $A C / C e-H_{2} S_{4} / M W C N T$ device at $1.5 \mathrm{~V}$ and $17.7 \mathrm{~mA} \mathrm{~cm}^{-2}$.

Table 2. Cell or electrode capacitances $\left(C, C_{+}, C_{-}\right)$and energy density $(E)$ values calculated in the different zones for the $\mathrm{AC} / \mathrm{Ce}-\mathrm{H}_{2} \mathrm{SO}_{4} / G F$ device at $1.5 \mathrm{~V}$ and $17.7 \mathrm{~mA} \mathrm{~cm}{ }^{-2}$. 


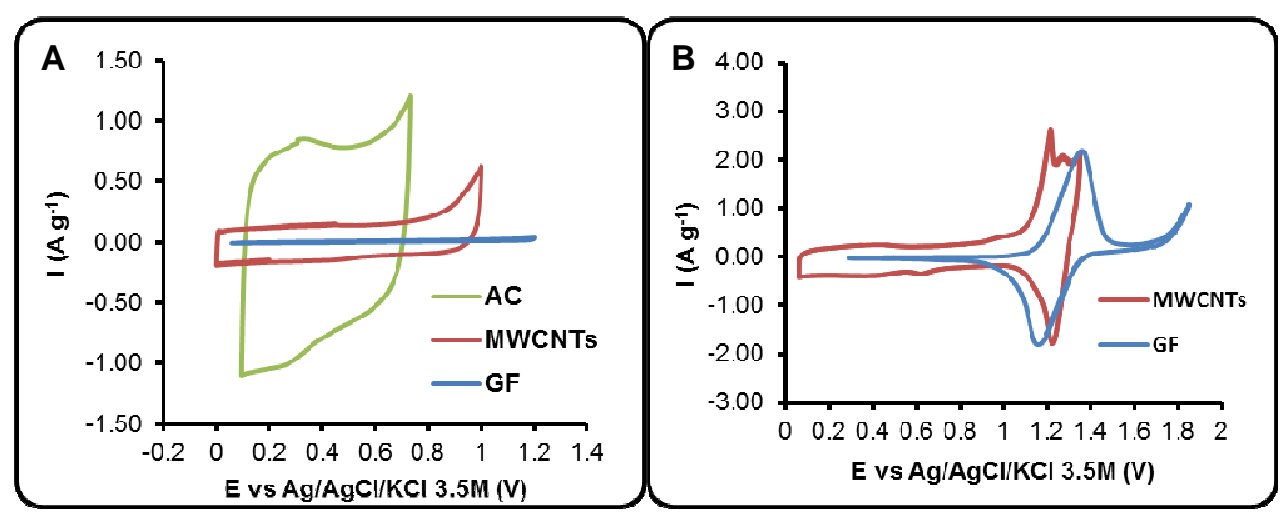

Fig. 1 


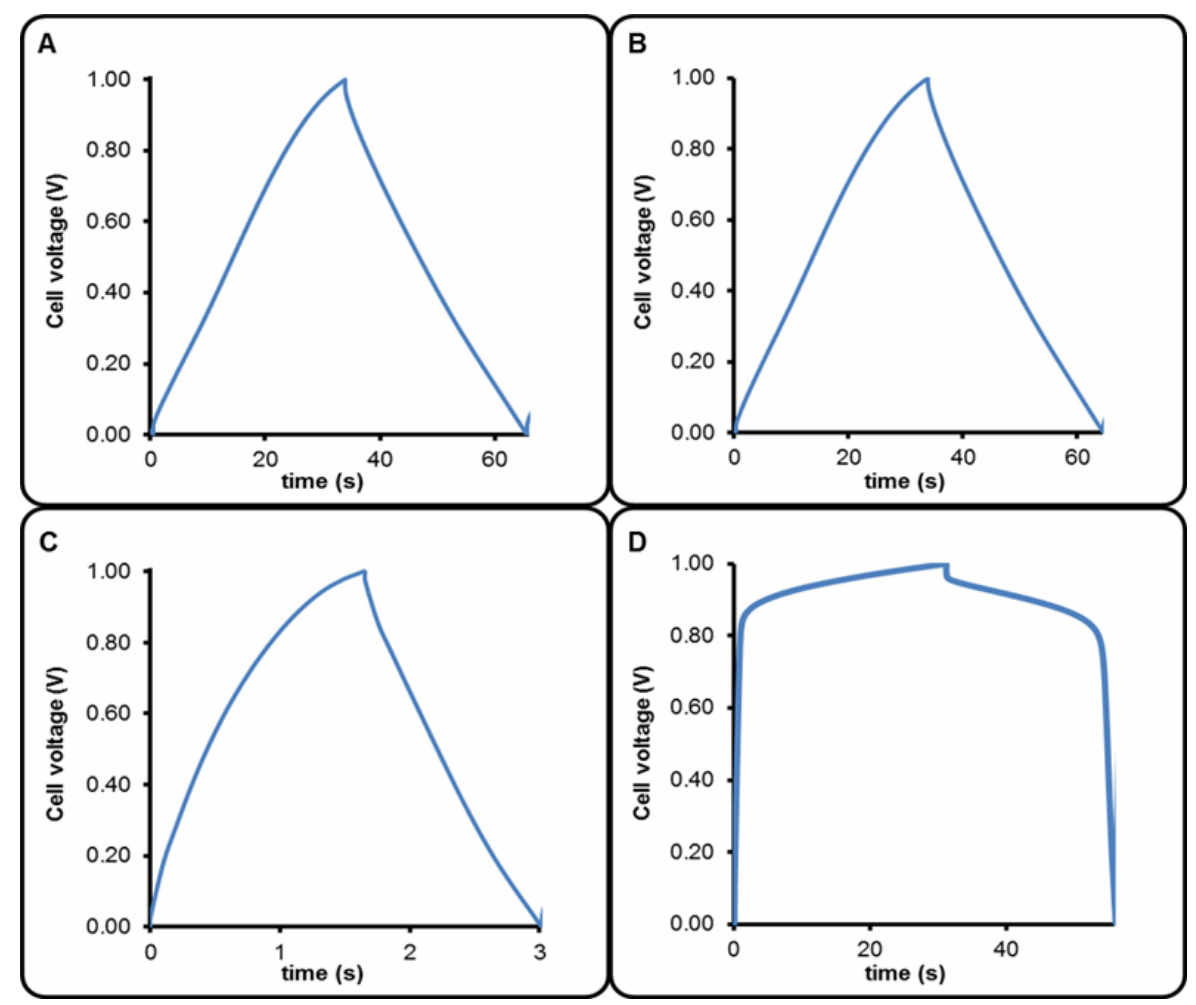

Fig. 2 


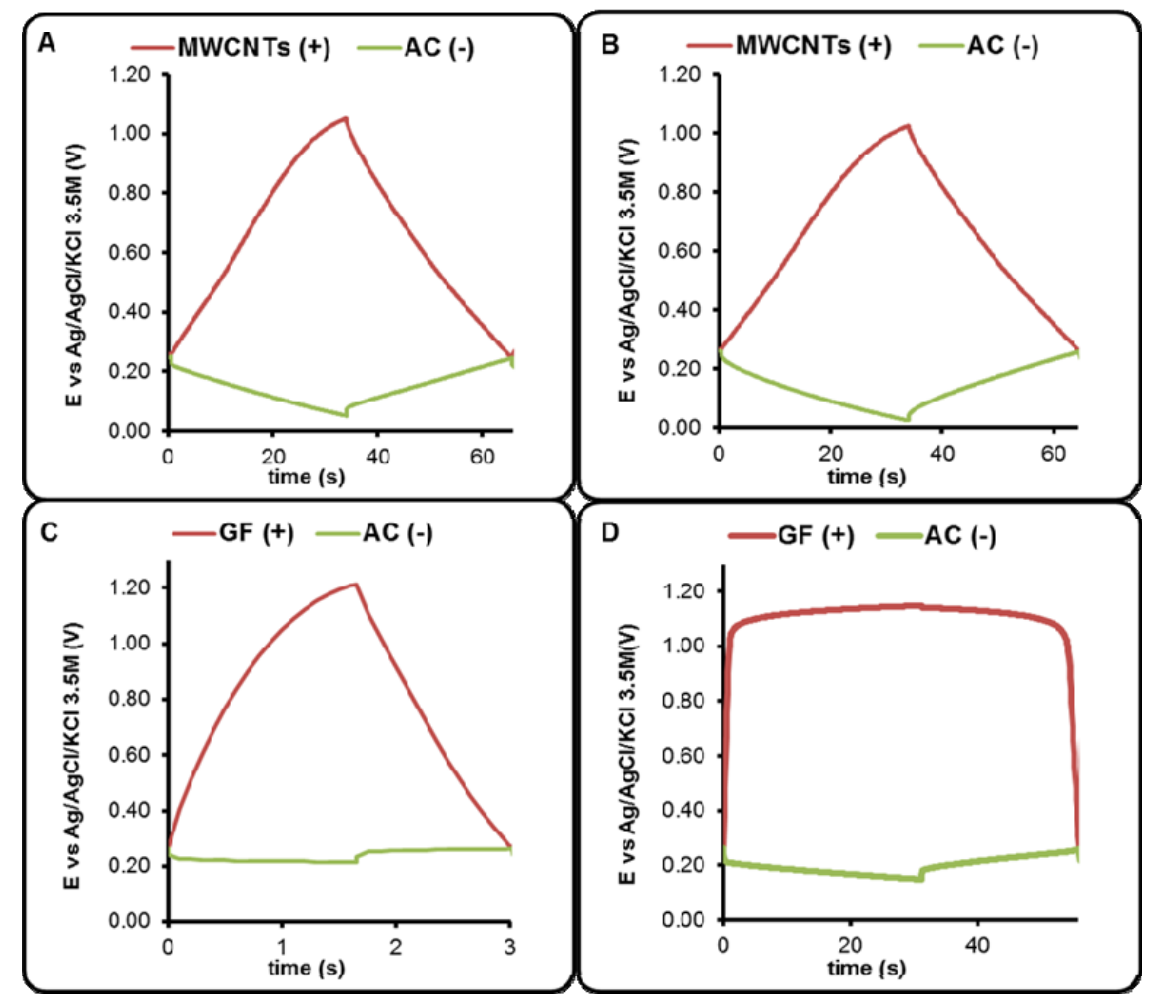

Fig. 3 


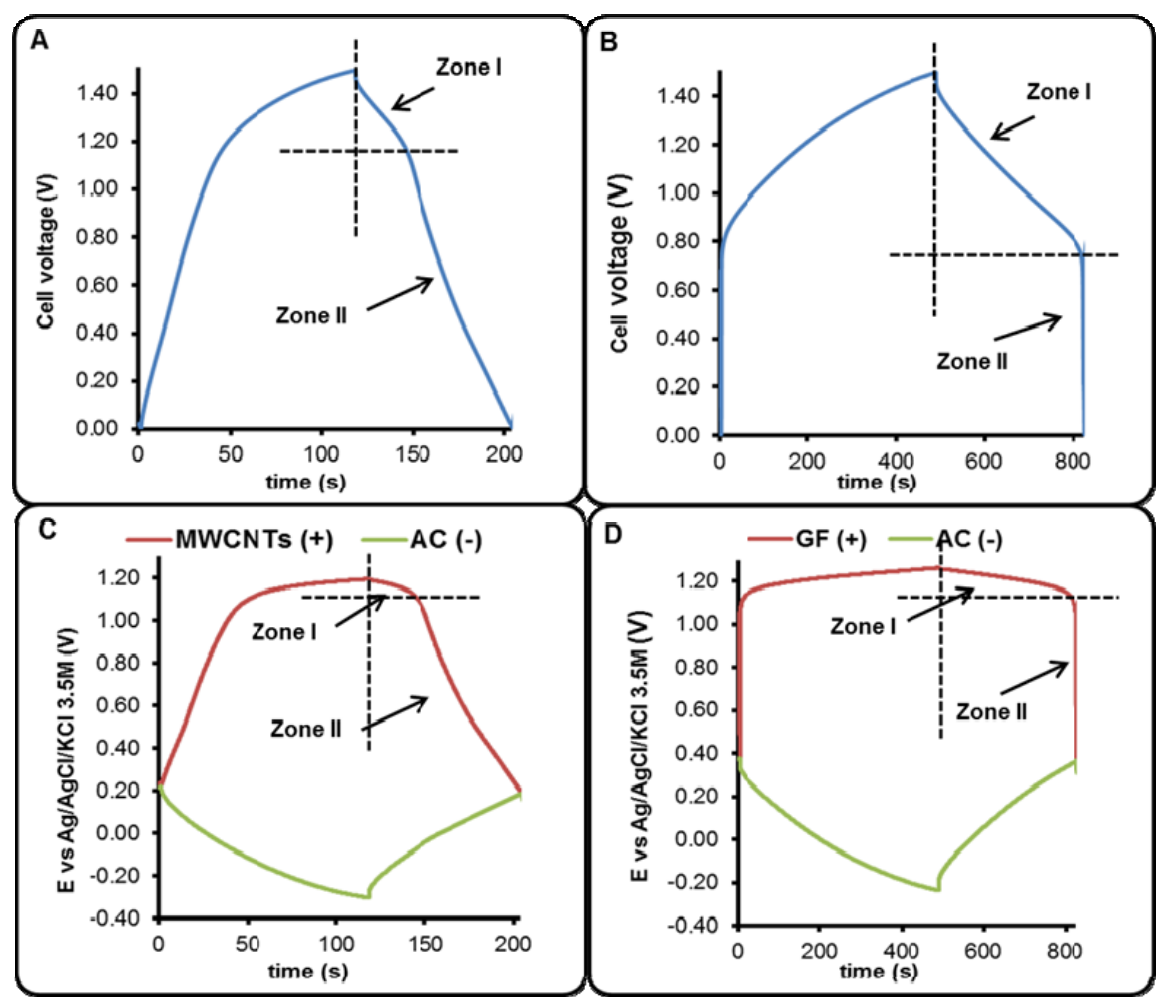

Fig. 4 


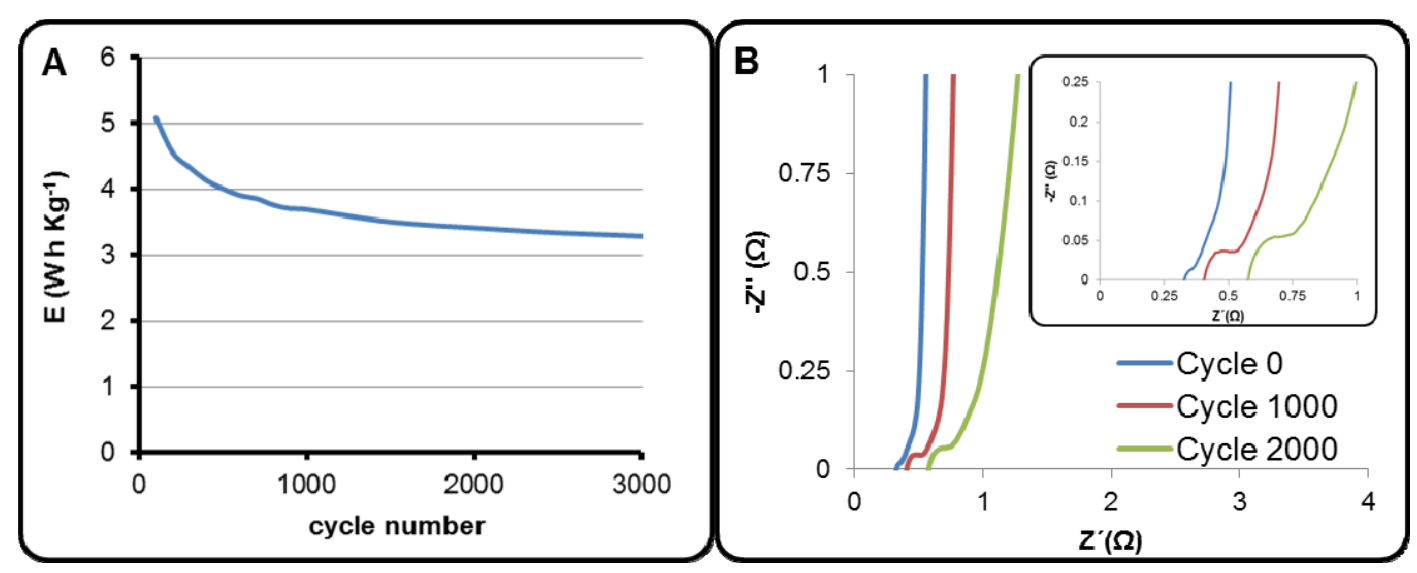

Fig. 5 


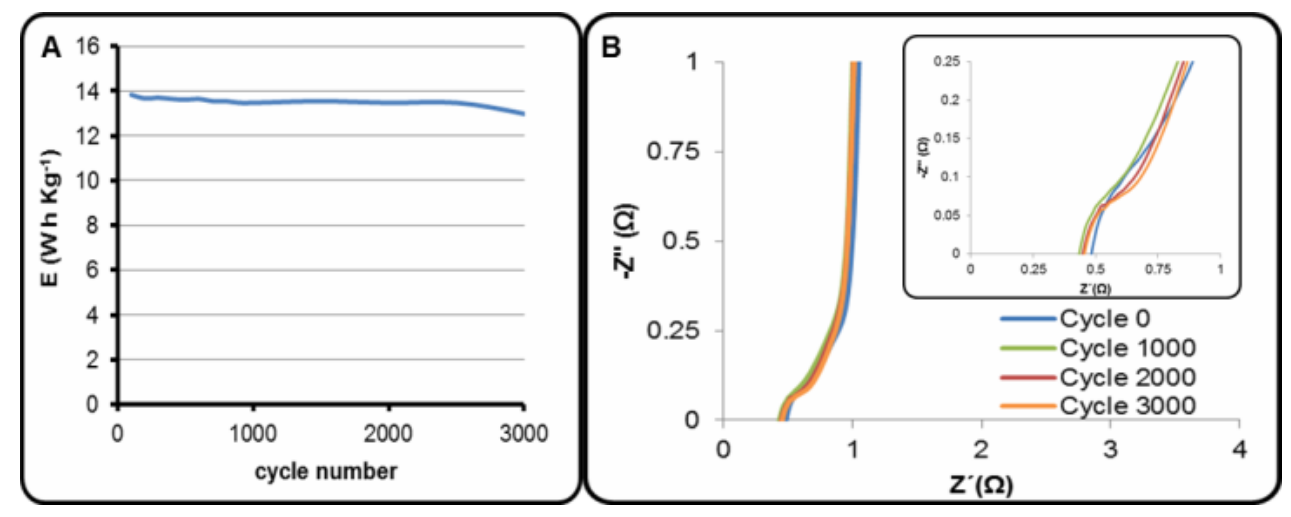

Fig. 6 
Table 1

\begin{tabular}{llllll}
\hline Zone I & $\Delta \mathrm{V}(\mathrm{V})$ & $\mathrm{C}\left(\mathrm{F} \mathrm{g}^{-1}\right)$ & $\mathrm{E}\left(\mathrm{W} \mathrm{h} \mathrm{kg}^{-1}\right)$ & Mechanism & Limiting \\
\hline Cell & 0.37 & 5 & 3.52 & & \\
MWCNTs & 0.15 & 124 & 5.20 & Faradaic & \\
AC & 0.23 & 85 & 0.92 & $\mathrm{DL}^{[\mathrm{a}]}$ & $\mathrm{X}$ \\
\hline Zone II & $\Delta \mathrm{V}(\mathrm{V})$ & $\mathrm{C}\left(\mathrm{F} \mathrm{g}^{-1}\right)$ & $\mathrm{E}\left(\mathrm{W} \mathrm{h} \mathrm{kg}^{-1}\right)$ & Mechanism & Limiting \\
\hline Cell & 1.11 & 3 & 2.73 & & \\
MWCNTs & 0.87 & 45 & 4.07 & $\mathrm{DL}^{[\mathrm{a}]}$ & $\mathrm{X}$ \\
AC & 0.24 & 174 & 2.18 & $\mathrm{DL}^{[\mathrm{a}]}$ & \\
\hline
\end{tabular}

[a] DL : Double Layer 
Table 2

\begin{tabular}{llllll}
\hline Zone I & $\Delta \mathrm{V}(\mathrm{V})$ & $\mathrm{C}\left(\mathrm{F} \mathrm{g}^{-1}\right)$ & $\mathrm{E}\left(\mathrm{W} \mathrm{h} \mathrm{kg}^{-1}\right)$ & Mechanism & Limiting \\
\hline Cell & 0.78 & 64 & 13.7 & & \\
$\mathrm{GF}$ & 0.18 & 408 & 14.7 & Faradaic & \\
$\mathrm{AC}$ & 0.60 & 232 & 7.5 & $\mathrm{DL}^{[\mathrm{a}]}$ & $\mathrm{X}$ \\
\hline Zone II & $\Delta \mathrm{V}(\mathrm{V})$ & $\mathrm{C}\left(\mathrm{F} \mathrm{g}^{-1}\right)$ & $\mathrm{E}\left(\mathrm{W} \mathrm{h} \mathrm{kg}^{-1}\right)$ & Mechanism & Limiting \\
\hline Cell & 0.72 & 4 & 0.67 & & \\
GF & 0.71 & 6 & 0.80 & $\mathrm{DL}^{[\mathrm{a}]}$ & $\mathrm{X}$ \\
AC & 0.01 & 343 & 0.95 & $\mathrm{DL}^{[\mathrm{a}]}$ & \\
\hline
\end{tabular}

[a] DL : Double Layer 